\title{
Matrix Metalloproteinase-9 Controls NMDA Receptor Surface Diffusion through Integrin $\beta 1$ Signaling
}

\author{
Piotr Michaluk, ${ }^{1,2}$ Lenka Mikasova, ${ }^{3}$ Laurent Groc, ${ }^{3}$ Renato Frischknecht, ${ }^{4}$ Daniel Choquet, ${ }^{3}$ and Leszek Kaczmarek ${ }^{1}$ \\ ${ }^{1}$ The Nencki Institute, 02-093 Warsaw, Poland, ${ }^{2}$ University Medical Center, 3584 CG Utrecht, The Netherlands, ${ }^{3}$ Unité Mixte de Recherche 5091, Centre \\ National de la Recherche Scientifique, Université Bordeaux 2, 33077 Bordeaux, France, and ${ }^{4}$ Leibniz Institute for Neurobiology, D-39118 Magdeburg, \\ Germany
}

Matrix metalloproteinase-9 (MMP-9) has emerged as a physiological regulator of NMDA receptor (NMDAR)-dependent synaptic plasticity and memory. The pathways by which MMP-9 affects NMDAR signaling remain, however, elusive. Using single quantum dot tracking, we demonstrate that MMP-9 enzymatic activity increases NR1-NMDAR surface trafficking but has no influence on AMPA receptor mobility. The mechanism of MMP-9 action on NMDAR is not mediated by change in overall extracellular matrix structure nor by direct cleavage of NMDAR subunits, but rather through an integrin $\beta 1$-dependent pathway. These findings describe a new target pathway for MMP-9 action in key physiological and pathological brain processes.

\section{Introduction}

Lateral diffusion of glutamate receptors within the plasma membrane provides a way for an efficient remodeling of postsynaptic signaling (Groc et al., 2008, 2009). AMPA receptor (AMPAR) lateral diffusion has attracted great interest, since it is modulated in response to neuronal activity (Borgdorff and Choquet, 2002; Tardin et al., 2003; Groc et al., 2004; Ehlers et al., 2007; Heine et al., 2008) and plasticity (Shi et al., 1999; Moga et al., 2006; Groc et al., 2008). Surface NMDA receptors (NMDARs) are less mobile than AMPARs and their lateral diffusion is not regulated by global changes in neuronal activity (Groc et al., 2004). However, recent data indicate that surface diffusion of different NMDAR subtypes plays a role in key synaptic adaptations [e.g., maturation (Groc et al., 2006, 2007), plasticity (Bellone and Nicoll, 2007), and metaplasticity (Zhao et al., 2008)].

Matrix metalloproteinases (MMPs) are extracellularly acting endopeptidases capable of cleaving extracellular matrix (ECM) along with several types of adhesion molecules (Woessner and Nagase, 2000). MMPs are mostly secreted in an inactive (pro-) form and are activated by proteolytic removal of a propeptide (Woessner and Nagase, 2000). They control remodeling of ECM environment and may influence cell signaling via either activation or release of bioactive molecules (Sternlicht and Werb, 2001). In the mature brain, the activity of MMPs (especially that of MMP-9) has been associated with remodeling related to injury, epilepsy, inflammation, etc. (Zhang et al., 1998; Wang et al.,

\footnotetext{
Received Nov. 6, 2008; revised March 23, 2009; accepted March 27, 2009.

This work was supported by the Polish Ministry of Science and Higher Education Research Grant 2 P04A 00930 , Sixth Framework Programme European Union Glutamate Receptor Interacting Proteins as Novel Neuroprotective Targets grant, and Foundation for Polish Science. We are grateful to Katherine Fisher (Pfizer) for providing CDNA of autoactivating MMP-9 mutant and Prof. F. Anne Stephenson for providing anti-NR1 antibody. We also thank Prof. E. D. Gundelfinger, and L. Bard for critical reading of this manuscript.

Correspondence should be addressed to Leszek Kaczmarek, The Nencki Institute, Pasteur 3, 02-093 Warsaw, Poland. E-mail: I.kaczmarek@nencki.gov.pl.

DOI:10.1523/JNEUROSCI.5346-08.2009

Copyright $\odot 2009$ Society for Neuroscience $\quad$ 0270-6474/09/296007-06\$15.00/0
}

2000; Szklarczyk et al., 2002; Yong, 2005; Wilczynski et al., 2008). Involvement of MMP-9 in NMDAR-dependent synaptic plasticity, as well as learning and memory, has recently been reported (Meighan et al., 2006; Nagy et al., 2006; Bozdagi et al., 2007; Michaluk and Kaczmarek, 2007). Moreover, we have recently found that MMP-9 colocalizes with NMDARs and AMPARs (Wilczynski et al., 2008; Gawlak et al., 2009). Furthermore, MMP-9 cleaves $\beta$-dystroglycan, a postsynaptic protein that may indirectly interact with glutamate receptors via dystrophin-actinin connection (James et al., 1996; Wyszynski et al., 1997; Michaluk et al., 2007). In the present study, we have tested the hypothesis that MMP-9 influences surface trafficking of NMDARs and found that this action is mediated by integrins.

\section{Materials and Methods}

Cell culture and synaptic live staining. Cultures of hippocampal neurons were prepared from embryonic day 18 Sprague Dawley rats following a method previously described (Goslin and Banker, 1998; Tardin et al., 2003 ) and maintained for 14-18 d in vitro (DIV). For synaptic live staining, the cells were incubated for $1 \mathrm{~min}$ at room temperature (RT) with 50 nM Green Mitotracker (Invitrogen; M-7514) before the imaging experiments. As indicated, cells were also incubated overnight with anti-CD29 (integrin $\beta_{1}$ chain) antibody (BD Biosciences Pharmingen; 555002) at final concentration of $40 \mu \mathrm{g} / \mathrm{ml}$ (Groc et al., 2007).

Single quantum dot tracking and surface diffusion calculation. Experiments involved live tracking of quantum dots (QDs) 655 goat $\mathrm{F}\left(\mathrm{ab}^{\prime}\right)_{2}$ anti-rabbit (Invitrogen; Q11422MP; for NR1 detection) or anti-mouse (Invitrogen; Q11022MP; for GluR2 detection). Surface NR1-NMDARs were stained for $10 \mathrm{~min}$ at $37^{\circ} \mathrm{C}$ with antibody preincubated with QDs (Groc et al., 2004). Surface GluR2-AMPARs were first stained with monoclonal anti-GluR2 antibody (1:500; BD Biosciences Pharmingen; 556341) for $10 \mathrm{~min}$ at $37^{\circ} \mathrm{C}$ in conditioned culture medium and then with QDs (1:2000) for $5 \mathrm{~min}$ at $37^{\circ} \mathrm{C}$ in the medium. All recording sessions were performed within $25 \mathrm{~min}$ after QD incubation to minimize the effect of receptor endocytosis (Groc et al., 2004).

Images were obtained on Nikon microscope equipped with $100 \times$ oilimmersion objective and Micromax CCD camera. Images were acquired at rate of 1 frame per $50 \mathrm{~ms}$ for 800 frames and processed with the 
a

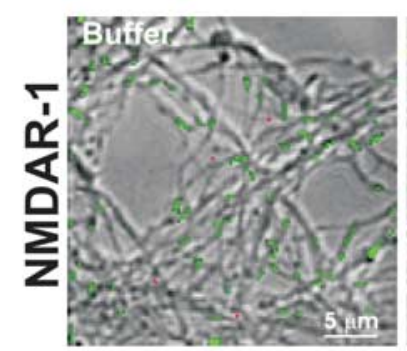

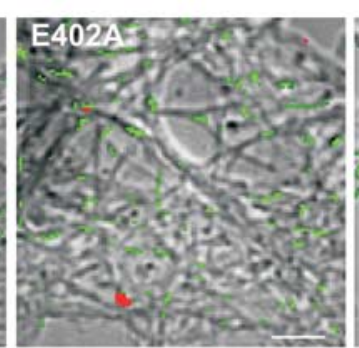

e

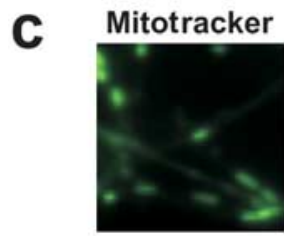

d

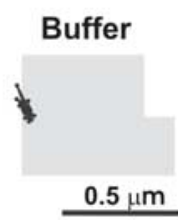

QD
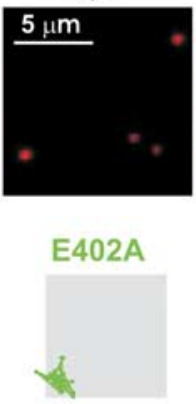

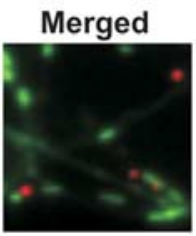

MMP-9

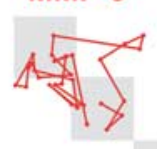

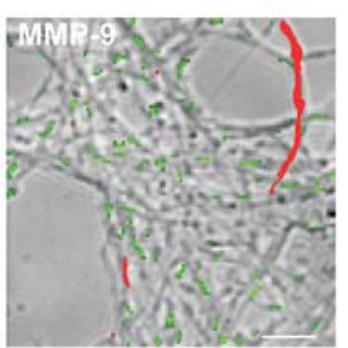

b

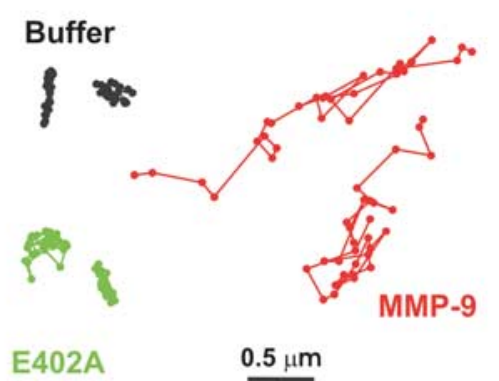

f

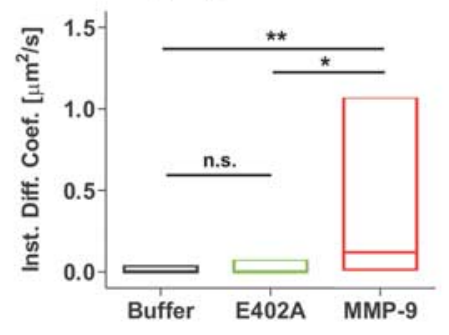

Extrasynaptic NMDAR1

Synaptic NMDAR1

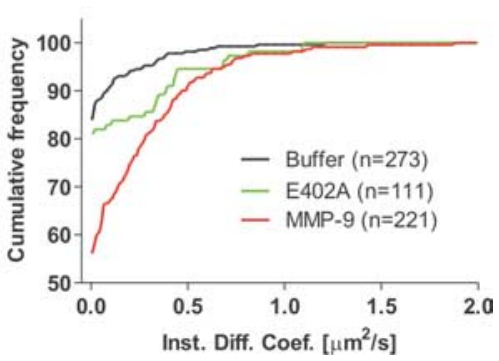

Figure 1. Proteolytic activity of MMP-9 is sufficient to increase NMDAR mobility. $\boldsymbol{a}$, Representative summed trajectories of QDs coupled with NR1 subunit antibody (a single red trace corresponds to the whole trajectory of a single QD-NR1 antibody complex). Synapses were stained with Mitotracker (green). In control conditions (buffer or E402A), QDs display immobile (dot-like) trajectories, but after treatment with autoactivating MMP-9, QDs are much more diffusive. $\boldsymbol{b}$, Examples of extrasynaptic trajectories of stained NMDAR1. c, Example image showing colocalization of Mitotracker signal (synapses) and QD (NMDARs) signal on single frame. $\boldsymbol{d}$, Examples of synaptic trajectories of stained NMDAR1; the gray area represents the synaptic region. $\boldsymbol{e}$, Distribution of the instantaneous diffusion coefficients of synaptic NMDARs expressed as median \pm IQR of $25-75 \%{ }^{*} p<0.05 ;{ }^{* *} p<0.005 . f$, Cumulative frequency of the instantaneous diffusion coefficients of extrasynaptic NR1. The first point of the distribution corresponds to the percentage of immobile receptors. Treatment with MMP-9 decreases the percentage of immobile receptors from $84 \%$ (buffer) or $81 \%$ (E402A) to $56 \%$. Kruskal-Wallis ANOVA by rank revealed significant differences between groups of extrasynaptic NMDAR mobility $(H=67.98 ; p<0.0001)$ and synaptic NMDAR mobility $(H=11.84 ; p=$ 0.0027). Post hoc Dunn's multiple-comparison test reached significance for extrasynaptic buffer versus MMP- $9(p<0.0001)$ and E402A versus MMP-9 $(p<0.0001)$ as well as for synaptic buffer versus MMP-9 $(p<0.005)$ and E402A versus MMP-9 $(p<0.05)$.

MetaMorph Software (Molecular Devices). QD tracking was performed as described previously (Tardin et al., 2003; Groc et al., 2004, 2006). Summed trajectories were drawn by linking points at which each QD was present in a single frame. Mean square displacement (MSD) curves were calculated for trajectories of at least 50 frames, and the instantaneous diffusion coefficient, $D$, was calculated for each trajectory, from linear fits of first four points of the MSD versus time function using $\operatorname{MSD}(t)=$ $\langle\mathrm{r} 2\rangle(t)=4 D t$, as reported previously (Harms et al., 2001a,b; Borgdorff and Choquet, 2002). The QDs were considered synaptic if colocalized with Mitotracker signal for at least three frames. For each condition, the membrane diffusion was calculated on three different cultures corresponding to $\sim 24$ different dendritic fields with an average of five QDs per field.

Recombinant autoactivating $M M P-9$ and inactive MMP-9 (E402A). Expression of autoactivating mutant of MMP-9 was performed as described previously (Michaluk et al., 2007). Inactive mutant of MMP-9-E402A was generated according to the QuikChange (Stratagene) manual; the point mutation changing $\mathrm{Glu}_{402}$ to Ala in catalytic center of human MMP-9 G100L mutant was inserted by PCR using the following pair of primers: TGGCGGCGCATGCGTTCGGCCACGC and GCGTGGCCGAACGCATGCGCCGCCA. Next E402A was cloned to pFastBac1 vector and expression and purification of protein was performed exactly as described above. Lack of enzymatic activity was checked in enzymatic test with EnzCheck gelatinase/collagenase assay kit (Invitrogen; E-12055) according to the manufacturer's instructions.

The cultures were treated with $400 \mathrm{ng} / \mathrm{ml}$ of either MMP-9 or E402A diluted in conditioned culture medium for $30 \mathrm{~min}$ and later stained for either glutamate receptors or ECM. For cathepsin G treatment, the neurons were incubated 20-40 min with $0.2 \mu \mathrm{M}$ cathepsin $\mathrm{G}$ (Calbiochem).

Immunostaining and confocal microscopy. Cells were fixed with paraformaldehyde, washed with PBS, blocked with 3\% BSA, and incubated for $2 \mathrm{~h}$ at $\mathrm{RT}$ with hyaluronic acid binding protein (HABP) coupled with Alexa 568 and rabbit anti-brevican Ab (1:2000) diluted in 1.5\% BSA. After three washes with PBS, cells were incubated with fluorescent (Alexa 488) secondary anti-rabbit antibody for $40 \mathrm{~min}$ at RT, washed, and mounted. Fluorescent specimens were examined under a spectral microscope (TCS SP2; Leica) equipped with $63 \times$ (1.32 numerical aperture) $488 \mathrm{~nm} \mathrm{Ar}$ and $543 \mathrm{~nm}$ GeNe laser for excitation of Alexa 488 and Alexa 568 , respectively. The images were acquired through the internal TCS SP2 detectors/photomultipliers. Sum of $Z$-stacks were analyzed in NIH ImageJ software. The results were calculated by multiplying average fluorescence per pixel and area analyzed, after subtracting the background.

\section{Results}

Enzymatic activity of MMP-9 increases lateral diffusion of NR1-NMDARs without cleavage of NR subunits

Using QD coupled to antibody directed against $\mathrm{N}$ terminus of NR1 subunit, we tracked single QD in the extrasynaptic and synaptic membranes of 14-18 DIV hippocampal neurons (Groc et al., 2004). The presence of recombinant MMP-9 markedly increased the surface diffusion (represented by instantaneous diffusion coefficient) of NR1-NMDAR both in the extrasynaptic [buffer median, $2.35 \times 10^{-4} \mathrm{\mu m}^{2} / \mathrm{s}$; interquartile range (IQR), $0.53 \times 10^{-4}-10.7 \times 10^{-4} \mu \mathrm{m}^{2} / \mathrm{s} ; n=273$; MMP-9 median, $14.7 \times 10^{-4} \mu \mathrm{m}^{2} / \mathrm{s}$; IQR, $2.76 \times 10^{-4}-2098 \times 10^{-4} \mu \mathrm{m}^{2} / \mathrm{s} ; n=$ 221] and the synaptic (buffer median, $13.5 \times 10^{-4} \mu \mathrm{m}^{2} / \mathrm{s}$; IQR, $0.28 \times 10^{-4}-382 \times 10^{-4} \mu \mathrm{m}^{2} / \mathrm{s} ; n=20$; MMP-9 median, 0.12 $\mu \mathrm{m}^{2} / \mathrm{s}$; IQR, 0.011-1.07 $\mu \mathrm{m}^{2} / \mathrm{s} ; n=17$ ) membranes (Fig. 1). To investigate whether increase in NR1-NMDAR surface diffusion is caused by the enzymatic activity of MMP-9, we incubated neu- 
a
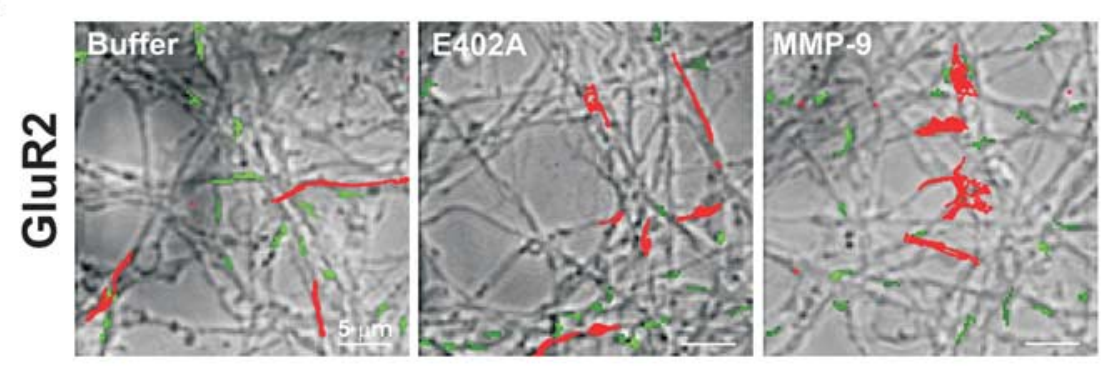

C

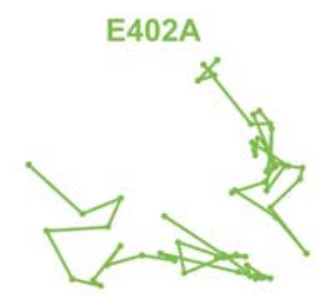

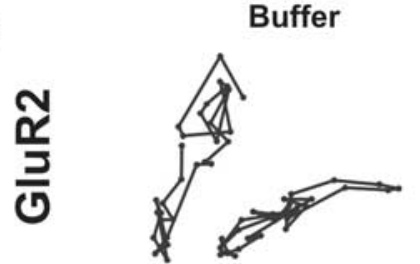

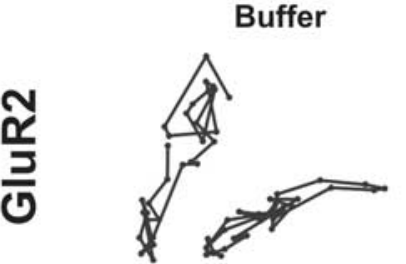

Buffer

$1 \mu \mathrm{m}$

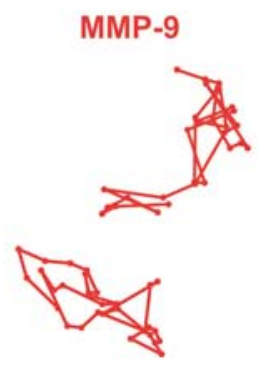

b
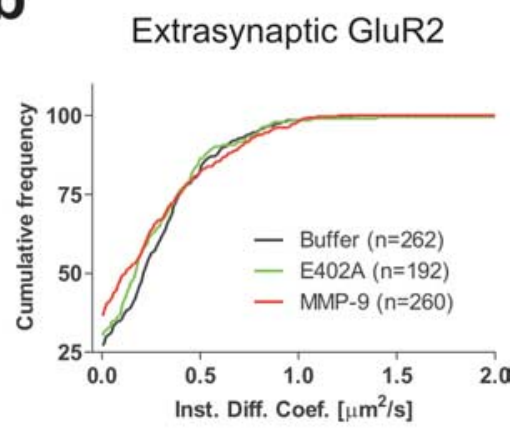

d

Synaptic GluR2

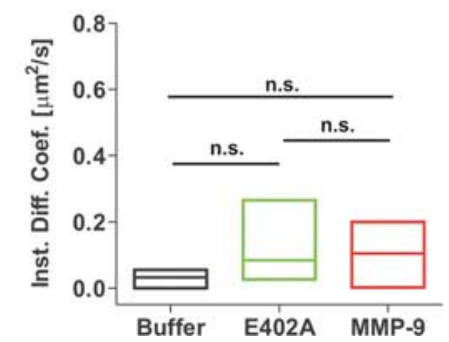

Figure 2. MMP-9 does not influence lateral diffusion of AMPARs. $\boldsymbol{a}$, Representative summed trajectories of QD coupled with GluR2 subunit antibody (a single red trace corresponds to the whole trajectory of a single QD-GluR2 antibody complex). Synapses were stained with Mitotracker (green). MMP-9 treatment does not change the generally diffusive nature of AMPARs. $\boldsymbol{b}$, Cumulative frequency of the instantaneous diffusion coefficients of extrasynaptic GluR2. Percentage of immobile receptors was $27 \%$ for incubation with buffer, $30 \%$ for E402A, and 37\% for MMP-9. Kruskal-Wallis ANOVA by rank did not reveal significant differences between groups of extrasynaptic AMPAR mobility $(H=2.743)$. $\boldsymbol{c}$, Examples of extrasynaptic trajectories of stained GluR2. $\boldsymbol{d}$, Distribution of the instantaneous diffusion coefficients of synaptic NMDARs expressed as median \pm IQR of $25-75 \%$. Kruskal-Wallis ANOVA by rank did not reveal significant differences between groups of synaptic AMPAR mobility $(H=2.909)$.

rons with MMP-9 inactive mutant (E402A). In this condition, no significant effect was observed for extrasynaptic (median, $2.16 \times$ $10^{-4} \mu \mathrm{m}^{2} / \mathrm{s}$; IQR, $\left.0.80 \times 10^{-4}-6.77 \times 10^{-4} \mu \mathrm{m}^{2} / \mathrm{s} ; n=111\right)$ and synaptic NMDARs mobilities (median, $1.99 \times 10^{-4} \mu \mathrm{m}^{2} / \mathrm{s}$; IQR, $0-764 \times 10^{-4} \mu \mathrm{m}^{2} / \mathrm{s} ; n=9$ ) (Fig. 1). Moreover, because other MMPs, such as MMP-3 and MMP-7, directly cleave the N terminus of NR1 subunits, we investigated whether MMP-9 effect on NMDAR trafficking resulted from a cleavage of NR subunits. In agreement with a recent study by Szklarczyk et al. (2008), neither NR1, NR2A, nor NR2B subunit was cleaved by MMP-9 as examined using Western blot approach (data not shown). Together, these results indicate that MMP-9 increase the surface diffusion of NR1-NMDARs through its enzymatic activity but without cleavage of the NR subunits. Notably, MMP-9 could play a role in physiology of our cultures as it as present in the cell culture medium at concentration of $0.6 \pm 0.066 \mathrm{ng} / \mathrm{ml}$.

\section{MMP-9 does not affect GluR2-AMPAR surface diffusion}

To examine whether MMP-9-induced increase in NMDAR mobility is selective for these receptors or it affects other glutamate receptors, the cells were incubated with active MMP-9 and lateral diffusion of GluR-2-containing AMPARs was analyzed. The surface mobility of synaptic (buffer median, $32.8 \times 10^{-3} \mu \mathrm{m}^{2} / \mathrm{s}$; IQR, $0.11 \times 10^{-3}-55.1 \times 10^{-3} \mu \mathrm{m}^{2} / \mathrm{s} ; n=14 ;$ E402A median, $84.5 \times 10^{-3} \mu \mathrm{m}^{2} / \mathrm{s}$; IQR, $25.9 \times 10^{-3}-265 \times 10^{-3} \mu \mathrm{m}^{2} / \mathrm{s} ; n=$ 8; MMP-9 median, $105 \times 10^{-3} \mu^{2} / \mathrm{s}$; IQR, $2.02 \times 10^{-3}-200 \times$ $10^{-3} \mu \mathrm{m}^{2} / \mathrm{s} ; n=11$ ) and extrasynaptic AMPARs was not changed (buffer median, $213 \times 10^{-3} \mu \mathrm{m}^{2} / \mathrm{s}$; IQR, $0.51 \times 10^{-3}$ $397 \times 10^{-3} \mu \mathrm{m}^{2} / \mathrm{s} ; n=262$; E402A median, $1.71 \times 10^{-3} \mu \mathrm{m}^{2} / \mathrm{s}$; IQR, $0.35 \times 10^{-3}-384 \times 10^{-3} \mu \mathrm{m}^{2} / \mathrm{s} ; n=192 ;$ MMP-9 median, $124 \times 10^{-3} \mu \mathrm{m}^{2} / \mathrm{s}$; IQR, $0.29 \times 10^{-3}-398 \times 10^{-3} \mu \mathrm{m}^{2} / \mathrm{s} ; n=$ 260) (Fig. 2).

\section{Cathepsin G, has no significant effect on either NR1- NMDARs or GluR2-AMPARs}

To investigate whether another endopeptidase, which acts extracellularly (Iacoviello et al., 1995), may produce similar effect as MMP-9 on NMDAR surface diffusion, we tracked surface NR1NMDARs and GluR2-AMPARs in the presence of cathepsin G $(0.2 \mu \mathrm{M})$ (Iacoviello et al., 1995). The surface diffusion of NR1NMDARs was not significantly affected by cathepsin G incubation in either the extrasynaptic (extrasynaptic NR1-NMDAR median, $5.7 \times 10^{-3} \mu \mathrm{m}^{2} / \mathrm{s}$; IQR, $1.8 \times 10^{-3}-3.7 \times 10^{-2} \mu \mathrm{m}^{2} / \mathrm{s}$; $n=975$; cathepsin median, $5.6 \times 10^{-3} \mu \mathrm{m}^{2} / \mathrm{s} ; \mathrm{IQR}, 1.6 \times 10^{-3}$ $\left.2.5 \times 10^{-2} \mu \mathrm{m}^{2} / \mathrm{s} ; n=453 ; p>0.05\right)$ or synaptic $(15 \pm 14 \%$ after cathepsin; $\left.p>0.05 ; n_{\text {control }}=45 ; n_{\text {cathepsin }}=32\right)$ compartment. Similarly, cathepsin G had no significant effect on the surface diffusion of extrasynaptic $(+33 \pm 15 \%$ after cathepsin; $p>$ $\left.0.05 ; n_{\text {control }}=975 ; n_{\text {cathepsin }}=453\right)$ or synaptic $(+29 \pm 23 \%$ after cathepsin; $p>0.05 ; n_{\text {control }}=51 ; n_{\text {cathepsin }}=25$ ) GluR2-AMPARs.

\section{MMP-9 affects NMDARs lateral diffusion via integrin signaling}

MMPs, because of their promiscuous substrate specificity, may degrade various components of the ECM (Mott and Werb, 2004) and thus could cause extensive changes in the ECM structure. We then tested whether increase in lateral mobility of NMDARs could be explained by this phenomenon. Thirty minute incubation of cultured neurons with recombinant MMP-9 did not alter gross ECM structure as visualized by either incubation with HABP conjugated with Alexa 568 or immunostaining against brevican (Fig. 3a).

MMP-9 has been shown to act via integrin signaling (Nagy et al., 2006), which plays also a role in NMDAR synaptic trans- 
a
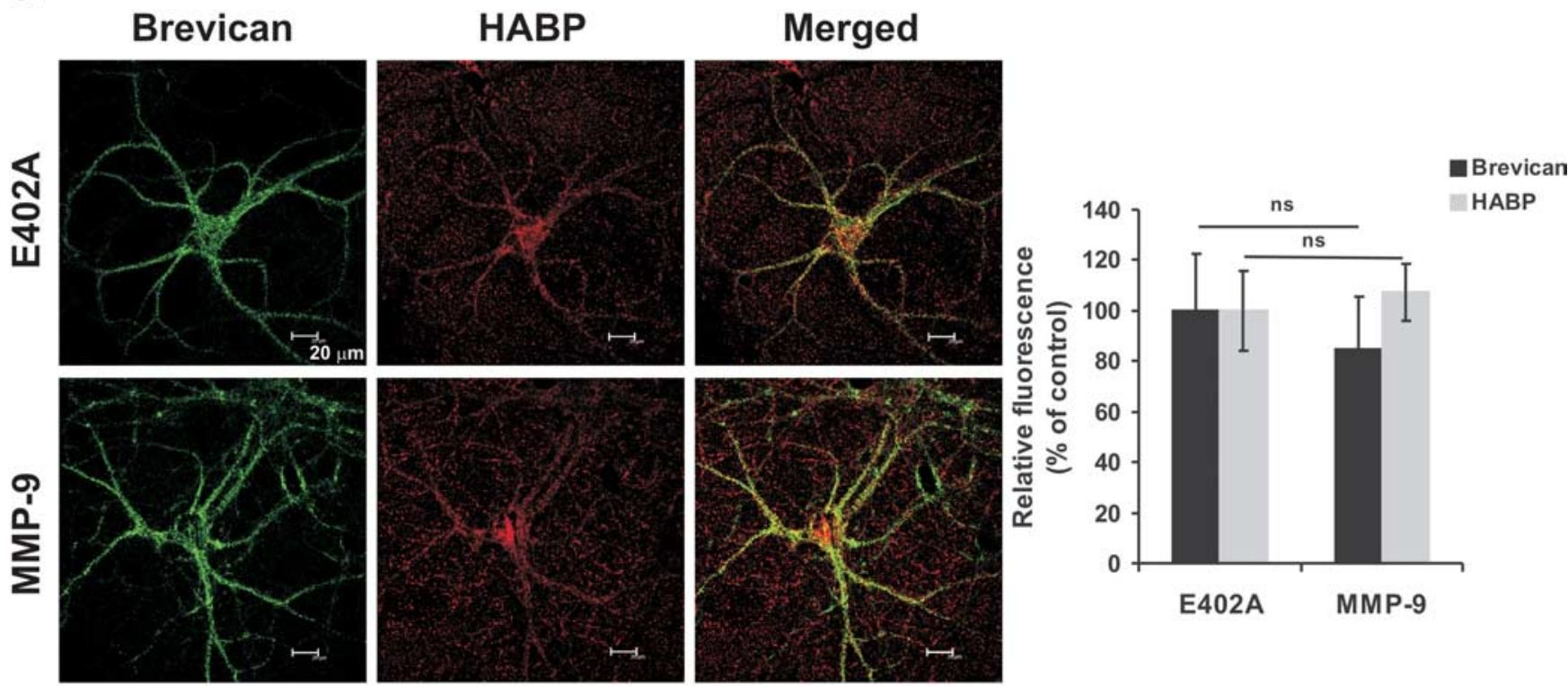

b

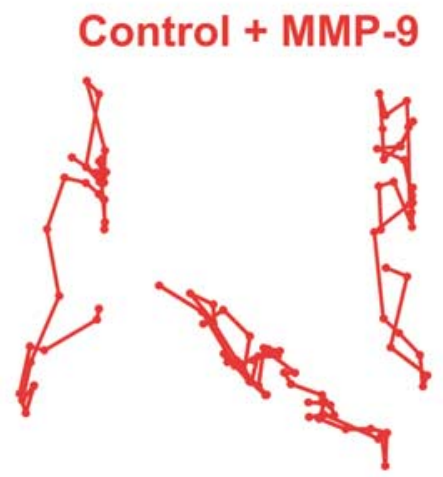

$A b+M M P-9$
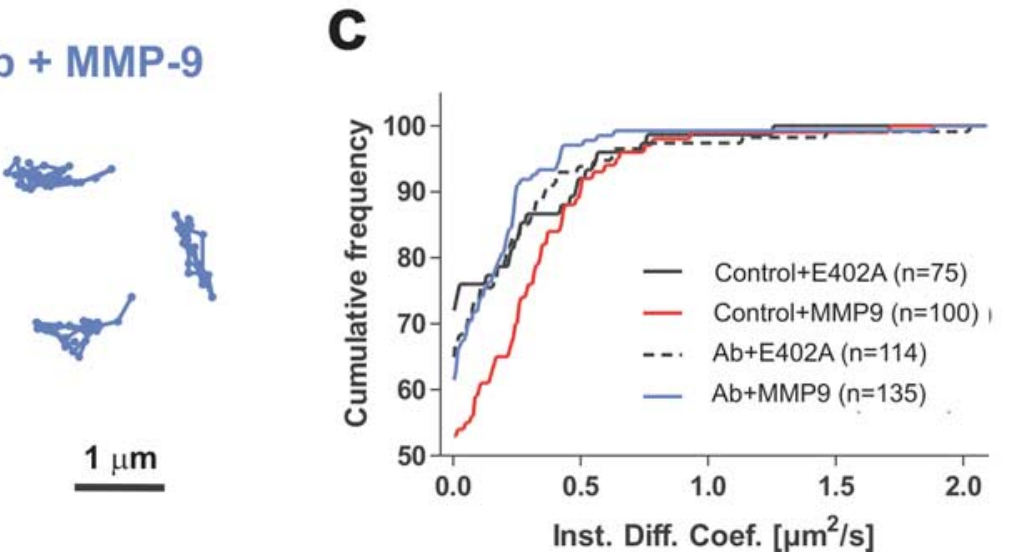

Figure 3. Influence of MMP-9 on NMDAR mobility is attributable to neither change in extracellular matrix structure nor cleavage of NMDAR subunits but is mediated via integrin signaling. $\boldsymbol{a}$, Neurons incubated 30 min with MMP-9 did not show change in overall structure of ECM as visualized by incubation of cells with HABP conjugated with Alexa 568 (red) or by staining cells with antibody anti-brevican (green). On right are the quantified relative fluorescence of brevican immunostaining and HABP labeling. Error bars indicate SEM. Mann-Whitney test did not reveal differences for brevican immunostaining $(U=106)$ and HABP labeling $(U=110)$. $\boldsymbol{b}$, Cells were incubated overnight with antibody blocking integrin $\beta_{1}$, and then incubated for 30 min with autoactivating MMP-9 to induce increase in NMDAR mobility. Examples of trajectories of stained NMDAR1 of cells incubated with autoactivating MMP-9 (red) and preincubated with anti-integrin antibody (blue). c, Graph shows cumulative distribution of the instantaneous diffusion coefficients of extrasynaptic NR1 in neurons treated with autoactivating MMP-9 or inactive E402A mutant. Ab, Integrin-blocking antibody; control, PBS. Treatment with MMP-9 decreases percentage of immobile receptors from 72 to $53 \%$, but preincubation with integrin blocking antibody reverses that effect. Mann-Whitney test revealed that mobility of NR1 of neurons preincubated with PBS and incubated with autoactivating MMP-9 is significantly different from control (control plus E402A vs control plus MMP-9; $U=2959, p=0.0171$ ) and that preincubation of neurons with antibody blocking integrin $\beta_{1}$ subunit abolished increase in mobility caused by MMP-9 (control plus MMP-9 vs Ab plus MMP-9; $U=5575, p=0.0226)$.

mission (Bernard-Trifilo et al., 2005) and NMDARdependent plasticity (Shi and Ethell, 2006). Our immunofluorescence data (data not shown) support the observation that integrins are expressed in dendritic/synaptic compartment in cultured hippocampal neurons (Shi and Ethell, 2006). Therefore, we investigated whether blocking integrin $\beta 1$ subunit with a specific antibody abolishes MMP-9-induced increase in surface NMDAR mobility. For this, hippocampal neurons were incubated with anti-integrin $\beta 1$ antibody (Groc et al., 2007 ) and then treated with either active or inactive MMP-9. Anti-integrin $\beta 1$ antibody did not affect NMDAR lateral diffusion by itself. However, in the presence of anti-integrin $\beta 1$ antibody, the effect of MMP-9 on surface mobility of extrasynaptic (control plus MMP-9 vs Ab plus MMP-9; $U=5575$, $p=0.0226$ ) and synaptic (control plus MMP-9 vs Ab plus MMP-9; $U=87.00, p=0.0327$ ) NMDARs was completely abolished (Fig. 3b,c). This indicates that recruitment and/or activation of $\beta 1$-integrin is required for the MMP-9-induced increase in NMDAR surface trafficking.

Although we did not intend to characterize the intracellular molecular cascade involved, we tested two kinases that have been implicated in various integrin- and NMDAR-dependent processes. We found that blockade of neither ERK (extracellular signal-regulated kinase) with $10 \mu \mathrm{M}$ UO126 [1,4-diamino-2,3dicyano-1,4-bis(2-aminophenylthio)butadiene] nor protein kinase C with $1 \mu \mathrm{M}$ Gö9676 [12-(2-cyanoethyl)-6,7,12,13tetrahydro-13-methyl-5-oxo-5H-indolo(2,3-a)pyrrolo (3,4-c)carbazole] abolishes the MMP-9-induced increase in NMDAR 
mobility (data not shown). The downstream signaling pathway thus remains to be further explored.

\section{Discussion}

In the present report, we demonstrate that MMP-9, an extracellularly acting endopeptidase, increases the surface trafficking of NMDARs without affecting GluR2-AMPARs. This effect is not mediated by a direct cleavage of an extracellular domain of NR subunits, but it involves $\beta 1$-integrin. Understanding the surface trafficking of NMDARs is of importance as it relates to a number of key cellular and molecular processes involved in synapse maturation, plasticity, and during NMDAR-dependent neuronal pathologies (Lau and Zukin, 2007; Groc et al., 2009). It was previously reported that protein kinase $\mathrm{C}$ activation and neuronal development may regulate NMDAR mobility (Fong et al., 2002; Groc et al., 2004, 2006, 2007) and are thus likely involved in various forms of neuronal connection refinements. Compared with the aforementioned paradigms, the effect of MMP-9 on NMDAR surface diffusion is particularly strong. Notably, MMP-9 affects both synaptic and extrasynaptic receptors, which undergo exchange between these membrane compartments (Tovar and Westbrook, 2002; Groc et al., 2006), indicating that MMP-9 is a highly potent regulator of NMDAR surface trafficking.

MMP-9 increases lateral diffusion of NMDARs through its enzymatic activity and not through protein-protein interaction, as its inactive mutant (E402A) was not affecting receptor mobility. In addition, incubating neurons with cathepsin G (Iacoviello et al., 1995) was without effect on NMDAR surface diffusion. Furthermore, MMP-9 and cathepsin G did not influence AMPARs surface mobility, further proving the specificity of MMP-9 action on NMDARs.

Because ECM might act as a spatial obstacle for membrane receptors, we investigated the impact of MMP-9 on ECM structure and found no gross alteration resulting from MMP-9 activity. Interestingly, hyaluronidase, which digests complex carbohydrates of the ECM, causes increase in AMPAR but not NMDAR mobility in hippocampal neurons (Frischknecht et al., 2009). Notably, MMP-9 action on NMDAR surface diffusion does not act through direct proteolytic cleavage of its subunits, as shown by Szklarczyk et al. (2008).

We show here that integrin $\beta 1$ antibody abolished MMP-9induced increase in NMDAR lateral diffusion. Interestingly, MMP-9 can act via integrin signaling (Nagy et al., 2006), and both proteins interact (Wang et al., 2003). We previously reported that another extracellular matrix protein, reelin, regulated bidirectionally the surface trafficking of NMDARs (and not AMPARs), and, interestingly, this effect was mediated by the activation of $\beta 1$ integrin (Groc et al., 2007). Together with the well known effects of the integrin activation on NMDAR transmission via phosphorylation pathways and synaptic plasticity (BernardTrifilo et al., 2005; Lynch et al., 2007), it now emerges that the presence of specific extracellular matrix proteins, such as MMP-9 or reelin, strongly and rapidly impact on the surface trafficking and signaling of NMDARs through the activation of integrins. Of course, other transmembrane or extracellular proteins might be involved in such physiological regulations, such as the Ephrin family, since EphrinB receptors interact with NMDAR (Dalva et al., 2000; Takasu et al., 2002) and are cleaved by MMP-9 (Lin et al., 2008).

Together, our results can be explained by MMP-9 driven release of some ECM molecule(s), which in turn may act as ligand(s) for integrins that next transfer a signal leading to an increase in lateral diffusion of NMDAR, but not AMPAR. Moreover, in contrast to a view of MMPs as rather unspecific ECMdegrading enzymes, our data suggest that MMP-9 is a highly specific enzyme, involved in complex, $\beta 1$ integrin-dependent signaling.

Our results could also be interpreted in the context of a recent study by Steiner et al. (2008) of destabilization and subsequent reorganization of the major NMDAR scaffolding protein, of PSD-95, whose CaMKII-dependent phosphorylation plays a role in initial triggering and later terminating of spine growth. Such destabilization of PSD-95 could result in increased lateral mobility of NMDAR. However, the importance of this destabilization for modulation of spine morphology could imply a similar role of MMP-9 in spine remodeling and thus explain its role in synaptic plasticity (Nagy et al., 2006; Meighan et al., 2007; Okulski et al., 2007; Wang et al., 2008).

\section{References}

Bellone C, Nicoll RA (2007) Rapid bidirectional switching of synaptic NMDA receptors. Neuron 55:779-785.

Bernard-Trifilo JA, Kramár EA, Torp R, Lin CY, Pineda EA, Lynch G, Gall CM (2005) Integrin signaling cascades are operational in adult hippocampal synapses and modulate NMDA receptor physiology. J Neurochem 93:834-849.

Borgdorff AJ, Choquet D (2002) Regulation of AMPA receptor lateral movements. Nature 417:649-653.

Bozdagi O, Nagy V, Kwei KT, Huntley GW (2007) In vivo roles for matrix metalloproteinase-9 in mature hippocampal synaptic physiology and plasticity. J Neurophysiol 98:334-344.

Dalva MB, Takasu MA, Lin MZ, Shamah SM, Hu L, Gale NW, Greenberg ME (2000) EphB receptors interact with NMDA receptors and regulate excitatory synapse formation. Cell 103:945-956.

Ehlers MD, Heine M, Groc L, Lee MC, Choquet D (2007) Diffusional trapping of GluR1 AMPA receptors by input-specific synaptic activity. Neuron 54:447-460.

Fong DK, Rao A, Crump FT, Craig AM (2002) Rapid synaptic remodeling by protein kinase C: reciprocal translocation of NMDA receptors and calcium/calmodulin-dependent kinase II. J Neurosci 22:2153-2164.

Frischknecht R, Heine M, Perrais D, Seidenbecher CI, Choquet D, Gundelfinger ED (2009) Brain extracellular matrix afftects AMPA receptor lateral mobility and short-term synaptic plasticity. Nat Neurosci, in press.

Gawlak M, Górkiewicz T, Gorlewicz A, Konopacki FA, Kaczmarek L, Wilczynski GM (2009) High resolution in situ zymography reveals matrix metalloproteinase activity at glutamatergic synapses. Neuroscience 158:167-176.

Goslin K, Banker G (1998) Culturing nerve cells. Cambridge, MA: MIT.

Groc L, Heine M, Cognet L, Brickley K, Stephenson FA, Lounis B, Choquet D (2004) Differential activity-dependent regulation of the lateral mobilities of AMPA and NMDA receptors. Nat Neurosci 7:695-696.

Groc L, Heine M, Cousins SL, Stephenson FA, Lounis B, Cognet L, Choquet D (2006) NMDA receptor surface mobility depends on NR2A-2B subunits. Proc Natl Acad Sci U S A 103:18769-18774.

Groc L, Choquet D, Stephenson FA, Verrier D, Manzoni OJ, Chavis P (2007) NMDA receptor surface trafficking and synaptic subunit composition are developmentally regulated by the extracellular matrix protein Reelin. J Neurosci 27:10165-10175.

Groc L, Choquet D, Chaouloff F (2008) The stress hormone corticosterone conditions AMPAR surface trafficking and synaptic potentiation. Nat Neurosci 11:868-870.

Groc L, Bard L, Choquet D (2009) Surface trafficking of N-methyl-Daspartate receptors: physiological and pathological perspectives. Neuroscience 158:4-18.

Harms GS, Cognet L, Lommerse PH, Blab GA, Schmidt T (2001a) Autofluorescent proteins in single-molecule research: applications to live cell imaging microscopy. Biophys J 80:2396-2408.

Harms GS, Cognet L, Lommerse PH, Blab GA, Kahr H, Gamsjäger R, Spaink HP, Soldatov NM, Romanin C, Schmidt T (2001b) Single-molecule imaging of l-type $\mathrm{Ca}^{2+}$ channels in live cells. Biophys J 81:2639-2646.

Heine M, Groc L, Frischknecht R, Béique JC, Lounis B, Rumbaugh G, Huga- 
nir RL, Cognet L, Choquet D (2008) Surface mobility of postsynaptic AMPARs tunes synaptic transmission. Science 320:201-205.

Iacoviello L, Kolpakov V, Salvatore L, Amore C, Pintucci G, de Gaetano G, Donati MB (1995) Human endothelial cell damage by neutrophilderived cathepsin G. Role of cytoskeleton rearrangement and matrixbound plasminogen activator inhibitor-1. Arterioscler Thromb Vasc Biol 15:2037-2046.

James M, Nguyen TM, Wise CJ, Jones GE, Morris GE (1996) Utrophindystroglycan complex in membranes of adherent cultured cells. Cell Motil Cytoskeleton 33:163-174.

Lau CG, Zukin RS (2007) NMDA receptor trafficking in synaptic plasticity and neuropsychiatric disorders. Nat Rev Neurosci 8:413-426.

Lin KT, Sloniowski S, Ethell DW, Ethell IM (2008) Ephrin-B2-induced cleavage of EphB2 receptor is mediated by matrix metalloproteinases to trigger cell repulsion. J Biol Chem 283:28969-28979.

Lynch G, Rex CS, Gall CM (2007) LTP consolidation: substrates, explanatory power, and functional significance. Neuropharmacology 52:12-23.

Meighan PC, Meighan SE, Davis CJ, Wright JW, Harding JW (2007) Effects of matrix metalloproteinase inhibition on short- and long-term plasticity of Schaffer collateral/CA1 synapses. J Neurochem 102:2085-2096.

Meighan SE, Meighan PC, Choudhury P, Davis CJ, Olson ML, Zornes PA, Wright JW, Harding JW (2006) Effects of extracellular matrixdegrading proteases matrix metalloproteinases 3 and 9 on spatial learning and synaptic plasticity. J Neurochem 96:1227-1241.

Michaluk P, Kaczmarek L (2007) Matrix metalloproteinase-9 in glutamatedependent adult brain function and dysfunction. Cell Death Differ 14:1255-1258.

Michaluk P, Kolodziej L, Mioduszewska B, Wilczynski GM, Dzwonek J, Jaworski J, Gorecki DC, Ottersen OP, Kaczmarek L (2007) Betadystroglycan as a target for MMP-9, in response to enhanced neuronal activity. J Biol Chem 282:16036-16041.

Moga DE, Shapiro ML, Morrison JH (2006) Bidirectional redistribution of AMPA but not NMDA receptors after perforant path simulation in the adult rat hippocampus in vivo. Hippocampus 16:990-1003.

Mott JD, Werb Z (2004) Regulation of matrix biology by matrix metalloproteinases. Curr Opin Cell Biol 16:558-564.

Nagy V, Bozdagi O, Matynia A, Balcerzyk M, Okulski P, Dzwonek J, Costa RM, Silva AJ, Kaczmarek L, Huntley GW (2006) Matrix metalloproteinase-9 is required for hippocampal late-phase long-term potentiation and memory. J Neurosci 26:1923-1934.

Okulski P, Jay TM, Jaworski J, Duniec K, Dzwonek J, Konopacki FA, Wilczynski GM, Sánchez-Capelo A, Mallet J, Kaczmarek L (2007) TIMP-1 abolishes MMP-9-dependent long-lasting long-term potentiation in the prefrontal cortex. Biol Psychiatry 62:359-362.

Shi SH, Hayashi Y, Petralia RS, Zaman SH, Wenthold RJ, Svoboda K, Malinow R (1999) Rapid spine delivery and redistribution of AMPA receptors after synaptic NMDA receptor activation. Science 284:1811-1816.

Shi Y, Ethell IM (2006) Integrins control dendritic spine plasticity in hippocampal neurons through NMDA receptor and $\mathrm{Ca}^{2+} /$ calmodulindependent protein kinase II-mediated actin reorganization. J Neurosci 26:1813-1822.
Steiner P, Higley MJ, Xu W, Czervionke BL, Malenka RC, Sabatini BL (2008) Destabilization of the postsynaptic density by PSD-95 serine 73 phosphorylation inhibits spine growth and synaptic plasticity. Neuron 60:788-802.

Sternlicht MD, Werb Z (2001) How matrix metalloproteinases regulate cell behavior. Annu Rev Cell Dev Biol 17:463-516.

Szklarczyk A, Lapinska J, Rylski M, McKay RD, Kaczmarek L (2002) Matrix metalloproteinase- 9 undergoes expression and activation during dendritic remodeling in adult hippocampus. J Neurosci 22:920-930.

Szklarczyk A, Ewaleifoh O, Beique JC, Wang Y, Knorr D, Haughey N, Malpica T, Mattson MP, Huganir R, Conant K (2008) MMP-7 cleaves the NR1 NMDA receptor subunit and modifies NMDA receptor function. FASEB J 22:3757-3767.

Takasu MA, Dalva MB, Zigmond RE, Greenberg ME (2002) Modulation of NMDA receptor-dependent calcium influx and gene expression through EphB receptors. Science 295:491-495.

Tardin C, Cognet L, Bats C, Lounis B, Choquet D (2003) Direct imaging of lateral movements of AMPA receptors inside synapses. EMBO J 22:4656-4665.

Tovar KR, Westbrook GL (2002) Mobile NMDA receptors at hippocampal synapses. Neuron 34:255-264.

Wang X, Jung J, Asahi M, Chwang W, Russo L, Moskowitz MA, Dixon CE, Fini ME, Lo EH (2000) Effects of matrix metalloproteinase-9 gene knock-out on morphological and motor outcomes after traumatic brain injury. J Neurosci 20:7037-7042.

Wang XB, Bozdagi O, Nikitczuk JS, Zhai ZW, Zhou Q, Huntley GW (2008) Extracellular proteolysis by matrix metalloproteinase- 9 drives dendritic spine enlargement and long-term potentiation coordinately. Proc Natl Acad Sci U S A 105:19520-19525.

Wang XQ, Sun P, Paller AS (2003) Ganglioside GM3 inhibits matrix metalloproteinase- 9 activation and disrupts its association with integrin. J Biol Chem 278:25591-25599.

Wilczynski GM, Konopacki FA, Wilczek E, Lasiecka Z, Gorlewicz A, Michaluk P, Wawrzyniak M, Malinowska M, Okulski P, Kolodziej LR, Konopka W, Duniec K, Mioduszewska B, Nikolaev E, Walczak A, Owczarek D, Gorecki DC, Zuschratter W, Ottersen OP, Kaczmarek L (2008) Important role of matrix metalloproteinase 9 in epileptogenesis. J Cell Biol 180:1021-1035.

Woessner JF, Nagase H (2000) Matrix metalloproteinases and TIMPs. Oxford, New York: Oxford UP.

Wyszynski M, Lin J, Rao A, Nigh E, Beggs AH, Craig AM, Sheng M (1997) Competitive binding of alpha-actinin and calmodulin to the NMDA receptor. Nature 385:439-442.

Yong VW (2005) Metalloproteinases: mediators of pathology and regeneration in the CNS. Nat Rev Neurosci 6:931-944.

Zhang JW, Deb S, Gottschall PE (1998) Regional and differential expression of gelatinases in rat brain after systemic kainic acid or bicuculline administration. Eur J Neurosci 10:3358-3368.

Zhao J, Peng Y, Xu Z, Chen RQ, Gu QH, Chen Z, Lu W (2008) Synaptic metaplasticity through NMDA receptor lateral diffusion. J Neurosci 28: $3060-3070$ 